\title{
Bioavailability of inorganic and organic phosphorus compounds to natural assemblages of microorganisms in Hawaiian coastal waters
}

\author{
Karin Björkman ${ }^{1}$, David M. Karl ${ }^{2}$ \\ ${ }^{1}$ Department of Zoology, Stockholm University, S-106 91 Stockholm, Sweden \\ ${ }^{2}$ School of Ocean and Earth Science and Technology, University of Hawaii, Honolulu, Hawaii 96822, USA
}

\begin{abstract}
The bioavailability of 7 organic and 2 inorganic phosphorus compounds to natural communities of coastal marine bacteria and phytoplankton was evaluated. A bioavailability factor $(B F)$ based on changes in the turnover time of the phosphate pool (measured using ${ }^{32} \mathrm{PO}_{4}$ ) in the absence and presence of selected phosphorus compounds, relative to positive controls receiving $\mathrm{PO}_{4}$, was calculated as an index of the relative microbial metabolic preference for each added compound. There were marked differences in the bioavailability factors of various substrates tested with values ranging from 0 to 0.2 . The results indicate that nucleotides were the most readily utilizable of the combined phosphorus compounds investigated. By comparison, the addition of selected monophosphate esters, either individually or in mixtures, had only a limited effect on orthophosphate $\left(\mathrm{PO}_{4}\right)$ flux. However, orthophosphate appeared to be the preferred and, apparently, universal substrate. The bacterialenriched size fraction $(<0.8 \mu \mathrm{m})$ comprised an average of $75 \%$ of the total phosphorus uptake measured in our samples. A large but variable percentage of the added organic and combined inorganic compounds accumulated outside the cells as soluble reactive phosphorus (SRP), indicating an efficient regeneration of orthophosphate from the various phosphorus compounds tested.
\end{abstract}

KEY WORDS: Phosphorus · Nutrients · Microorganisms

\section{INTRODUCTION}

Marine ecosystems have traditionally been regarded as nitrogen limited for primary and secondary production (Ryther \& Dunstan 1971, Goldman et al. 1979); however, recent studies have begun to challenge these conventional views (Smith et al. 1986). In the surface waters of the oligotrophic Pacific Ocean phosphorus uptake rates greatly exceed the combined rates of input from the thermocline below and the atmosphere above, so phosphorus must be intensely recycled within the epipelagic zone. Considering the already very low concentrations of soluble reactive phosphorus (SRP) and total dissolved phosphorus (TDP) in the upper levels of the tropical oceans (SRP $\leq 50 \mathrm{nM}$, TDP $\leq 350 \mathrm{nM}$ ), phosphorus regeneration and cycling may ultimately control primary production in selected areas of the world ocean (Perry \& Eppley 1981, Orrett \& Karl 1987).
Very little is known about the utilization pathways and bioavailability of dissolved organic phosphorus (DOP) or inorganic polyphosphate compounds in the marine environment despite the fact that these substrates often dominate the TDP pool in surface seawaters. Consequently, the cycling of TDP could potentially control phosphorus availability and affect the biomass and productivity of the phytoplankton and bacterial communities. The exploitation of combined phosphorus compounds requires the presence of specific hydrolytic enzymes, including alkaline phosphatase (Perry 1972) and 5'-nucleotidase (Ammerman \& Azam 1985).

Most studies of DOP bioavailability have been performed in limnetic systems (Berman 1988, Tarapchak \& Moll 1990, Bentzen \& Taylor 1991) under characteristically phosphorus-limited conditions. Several studies have investigated the bioavailability of naturally occurring DOP (Tarapchak \& Moll 1990, Cooper et al. 
1991), but in most cases specific organic and inorganic phosphorus compounds have been employed (Berman 1988, Bentzen \& Taylor 1991, Bentzen et al. 1992, Cotner \& Wetzel 1992).

There is also uncertainty as to whether phytoplankton or heterotrophic bacterioplankton is more efficient in sequestering phosphate from the environment or in using DOP as a source of phosphorus. In general, the experimental results have indicated that heterotrophic bacteria are more competitive in taking up phosphate (Currie \& Kalff 1984a, b, Currie 1986, Currie et al. 1986 Berman 1988, Jürgens \& Güde 1990), suggesting that algae may rely on DOP as a supplemental source of phosphorus (Tarapchak \& Moll 1990, Cotner \& Wetzel 1992). It has long been known that algae have the ability to utilize DOP in the absence of inorganic phosphorus (Chu 1946, Kuentzler 1965), but their efficiency in obtaining phosphorus in natural environments in competition with heterotrophic bacteria is unresolved. The existence in bacteria of high-affinity phosphorus transport systems (Chróst \& Overbeck 1987, Ammerman \& Azam 1991) and the presence of the enzyme 5'-nucleotidase (Ammerman \& Azam 1985, Tamminen 1989, Ammerman 1991, Cotner et al. 1991) together appear to contribute to their competitive advantage. The available data, however, are incomplete and, in part, contradictory. This could be the result of natural variability among the different habitats investigated or it may reflect actual differences in community composition in these studies.

The present study was designed to investigate the bioavailability of various organic and inorganic phosphorus compounds as sources of phosphorus for oligotrophic coastal marine microbial assemblages. The relative bioavailability of each compound was determined by measuring the sparing effect on the uptake rate of a radioactive tracer, ${ }^{32} \mathrm{PO}_{4}$, relative to $\mathrm{PO}_{4}$ unamended (negative control) and $\mathrm{PO}_{4}$-supplemented (positive control) treatments. Size fractionation experiments were also conducted to investigate the relative phosphorus uptake into the algal-or bacterial-enriched fractions.

\section{MATERIALS AND METHODS}

Sampling and site description. Surface seawaters $(0.5$ to $1 \mathrm{~m})$ were collected in acid-washed polycarbonate bottles (Nalgene) approximately $0.1 \mathrm{~km}$ off Magic Island on the southern coast of Oahu, Hawaii, USA, between November 1991 and August 1992. All experiments were performed in the laboratory under artificial illumination and at room temperature (15 to $30 \mu \mathrm{E}$ $\mathrm{m}^{-2} \mathrm{~s}^{-1}, 20^{\circ} \mathrm{C}$ ). The experiments commenced within $2 \mathrm{~h}$ after water collection. Two-hundred ml portions of sea- water were placed into $250 \mathrm{ml}$ acid-washed polycarbonate bottles (Nalgene) and were supplemented with individual organic or inorganic phosphorus compounds, or as mixtures of several compounds added at a $1 \mu \mathrm{M} P$ concentration. Radiolabelled ${ }^{32} \mathrm{PO}_{4}$ (carrier free; ICN Radiochemicals, catalog no. 64014 L) was used as a tracer in all experiments and was added immediately after the test compounds to yield a final activity of approximately $0.05 \mu \mathrm{Ci}{ }^{32} \mathrm{P} \mathrm{ml}^{-1}$. Specific radioactivity varied among the various experiments and treatments, but ranged from between 110 and $220 \mu \mathrm{Ci} \mu \mathrm{mol}^{-1} \mathrm{P}$ in the unsupplemented controls to between 15 and $70 \mu \mathrm{Ci} \mu \mathrm{mol}^{-1} \mathrm{P}$ in those supplemented with phosphorus. Negative controls consisted of unsupplemented seawater plus ${ }^{32} \mathrm{PO}_{4}\left(0.05 \mu \mathrm{Ci} \mathrm{ml}{ }^{-1}\right)$, and positive controls consisted of seawater with a 0.5 or $1 \mu \mathrm{M}$ addition of a phosphate standard (Wako Pure Chemical Industries Ltd) and labelled to the same radioactivity as the treated samples. The addition of $\mathrm{PO}_{4}$ over the range of 0 to $1 \mu \mathrm{M}$ resulted in the expected isotope dilution effect on ${ }^{32} \mathrm{PO}_{4}$ uptake, indicating that $\mathrm{PO}_{4}$ addition did not stimulate P-flux relative to the unamended controls

The compounds used as potential phosphorus sources were prepared as $200 \mu \mathrm{M}$ stock solutions in sterilefiltered $(0.22 \mu \mathrm{m})$ distilled water. Aliquots of each solution were stored at $-20^{\circ} \mathrm{C}$ to minimize hydrolysis. The specific compounds tested were: glucose-1-phosphate (G-1-P), fructose-1,6-diphosphate (F-1,6-P), phosphoenol pyruvate (PEP), glycerophosphate (GYP), adenosine triphosphate (ATP), uridine diphosphate (UDP), guanosine diphosphate (GDP) and sodium tripolyphosphate (PPP). All compounds were obtained from Sigma Chemical Company (St. Louis, MO, USA). Selected mixtures, prepared in equimolar phosphorus proportions, were also used. Mix A contained the monophosphate esters (G-1-P, F-1,6-P, PEP, GYP) and Mix $B$ contained the 3 nucleotides and polyphosphate (ATP, GDP, UDP, PPP).

The incubations were routinely subsampled and analyzed to determine whole water ${ }^{32} \mathrm{P}$ activity and particulate ${ }^{32} \mathrm{P}$ activity, the latter defined as activity retained on replicate $0.45 \mu \mathrm{m}$ HA Millipore filters. The use of $0.22 \mu \mathrm{m}$ Millipore GS filters did not substantially increase the particulate ${ }^{32} \mathrm{P}$ activities in these samples. Prior to use, the filters were soaked in phosphate solution $(0.5 \mu \mathrm{M})$ to reduce nonspecific ${ }^{32} \mathrm{P}$ adsorption and the collected particulate matter was washed 3 times with $1 \mathrm{ml}$ of $0.22 \mu \mathrm{m}$ filtered seawater. Samples of the filtrate were analyzed to provide a radiochemical mass balance. Post-incubation size fractionation experiments were carried out on several dates. For this analysis, replicate $10 \mathrm{ml}$ samples were filtered through $0.8 \mu \mathrm{m}$ Nuclepore filters. These filters were treated as described above. 
Due to the relatively low microbial biomasses and comparatively slow uptake rates in the habitats studied, the experiments typically were subsampled 3 to 6 times over a $24 \mathrm{~h}$ period. Samples for SRP and TDP were generally taken only at the start and end of each experiment. There were, however, occasions when the changes in SRP concentrations were monitored during the entire experiment. Duplicate or triplicate $10 \mathrm{ml}$ samples were taken and immediately frozen $\left(-20^{\circ} \mathrm{C}\right)$ until analyzed.

Analytical procedures. Radioactivity was determined by Cerenkov radiation using a Packard TriCarb $^{\oplus}$ scintillation counter. Counting efficiency was calculated to be $43 \%$.

SRP was analyzed using the molybdenum blue reaction described by Murphy \& Riley (1962), as modified by Strickland \& Parsons (1972). TDP samples were treated according to Jeffries et al. (1979), which employs an acidic (sulfuric acid) potassium persulphate $\left(\mathrm{K}_{2} \mathrm{~S}_{2} \mathrm{O}_{8}\right)$ oxidation procedure. Samples were autoclaved for $60 \mathrm{~min}$ at $121^{\circ} \mathrm{C}$ and were then treated the same as SRP samples. Phosphate concentrations were determined by absorption spectrophotometry at $880 \mathrm{~nm}$ (Varian, model DMS $100 \mathrm{~S}$ UV).

Uptake rates of ${ }^{32} \mathrm{P}$ incorporation into the particulate fraction were determined from the slope, calculated by least square regression analysis of the activity retained on filters over a time interval where the uptake was linear (e.g. the first 10 to $12 \mathrm{~h}$ of incubation). Turnover time ( $T)$ was calculated as:

$$
T=t / f
$$

where $t$ is incubation time (h) and $f$ is the fraction of total ${ }^{32} \mathrm{PO}_{4}$ incorporated into particulate matter during that incubation period. The rate of phosphate uptake, expressed as nM SRP $\mathrm{h}^{-1}$, was estimated from the specific radioactivity of the phosphate pool (calculated from the measured SRP concentration and the whole water activity) and the uptake rate of ${ }^{32} \mathrm{P}$. For those compounds that had a net accumulation of SRP over the course of the incubations (e.g. GYP and selected nucleotides), accumulation rate curves were established from time series experiments. SRP concentration at a given time point was calculated from these curves and was used to estimate the isotope dilution of the ${ }^{32} \mathrm{PO}_{4}$ tracer and, subsequently, the uptake rate of phosphate. Sterile controls confirmed that the apparent SRP increase was not simply the result of chemical hydrolysis of the phosphorus compounds.

Assuming that phosphorus is assimilated only in its inorganic form (Reid \& Wilson 1971, Chróst 1990), $\mathrm{PO}_{4}$ must be enzymatically cleaved from combined inorganic or organic compounds to render it accessible for uptake. It is then plausible that the uptake of ${ }^{32} \mathrm{PO}_{4}$ would target the same or similar uptake mechanisms as the $\mathrm{PO}_{4}$. A reduction in the apparent uptake rate of ${ }^{32} \mathrm{PO}_{4}$ in phosphorus-amended treatments would reflect an isotope dilution effect caused by phosphorus from exogenous sources. The apparent sparing effect of ${ }^{32}$ P-uptake with the addition of selected substrates, reflected as changes in the $\mathrm{PO}_{4}$ pool turnover time relative to the control incubation with no addition, is termed the bioavailability factor (BF):

$$
\mathrm{BF}=\left(T_{\mathrm{E}}-T_{\mathrm{N}}\right) /\left(T_{\mathrm{P}}-T_{\mathrm{N}}\right)
$$

where $T_{\mathrm{E}}=\mathrm{PO}_{4}$ pool turnover time in the experimental treatment ( $\mathrm{P}$ compounds added at $1 \mu \mathrm{M}$ concentrations), $T_{\mathrm{N}}=\mathrm{PO}_{4}$ pool turnover time in the negative control (no addition), and $T_{\mathrm{P}}=\mathrm{PO}_{4}$ pool turnover time in the positive control $\left(\mathrm{PO}_{4}\right.$ added, corrected to $1 \mu \mathrm{M}$ addition). In theory, $\mathrm{BF}$ ranges from 0 to 1 , with a value of 0 corresponding to an unavailable substrate and a value of 1 corresponding to a phosphorus compound that has a bioavailability equal to that of $\mathrm{PO}_{4}$.

\section{RESULTS}

\section{Uptake rates, turnover times and radiochemical mass balance}

The turnover times calculated for the negative control samples were generally between 20 and $40 \mathrm{~h}$, even though ambient SRP concentrations were low (60 to $160 \mathrm{nM})$. The uptake rates varied among different sampling dates but were usually in the 2 to $4 \mathrm{nM} \mathrm{h}^{-1}$ range (Table 1 ). In an earlier study using a range of added $\mathrm{PO}_{4}$ concentrations ( 0.16 to $0.65 \mu \mathrm{M}$ SRP), no change in uptake kinetics as a function of concentration was detected when corrected for the isotope dilution.

A radiochemical mass balance was achieved in all experiments for every sampling event over the entire incubation period. In the experimental results shown (Fig. 1), the sums of the activities found in the filtrate plus particulate fractions averaged $96.9 \pm 2.3 \%$ (negative control), $99.8 \pm 2.3 \%$ (positive control), $98.6 \pm 3.4 \%$ (Mix A) and $98.5 \pm 2.3 \%$ (Mix B) of the initial whole water activities $(n=6)$.

\section{Effects of adding of various phosphorus compounds}

There were distinct differences among the compounds tested with respect to the bioavailability factors (Table 1, Fig. 2). In general, nucleotides exhibited the greatest bioavailabilities, indicating that they were readily hydrolyzed by the Hawaiian coastal microbial assemblages. By comparison, the bioavailability of the monophosphate esters tested was consistently lower 
Table 1 Summary of 5 experiments reporting phosphorus concentrations, uptake rates, turnover times and the bioavailability factor $(\mathrm{BF})$ tor each separate date. All phosphorus compounds were added as a $1 \mu \mathrm{M}$ spike unless otherwise stated. The uptake rate was either the rate of uptake of the ${ }^{32} \mathrm{P}$-tracer $\left(\mu \mathrm{Ci}^{-1} \mathrm{~h}^{-1}\right)$ or the rate of total phosphate uptake $\left(\mathrm{nM} \mathrm{h}^{-1}\right)$. The latter value was corrected for isotope dilution. Turnover rates were based on the turnover of the label and thus reflect the increase of the phosphorus pool when the additional phosphorus substrates were included. Values are means \pm 1 SD; if no $S D$ is given then $n=1$ -: not measured on that date

\begin{tabular}{|c|c|c|c|c|c|c|c|c|}
\hline \multirow[t]{2}{*}{ Date } & \multirow[t]{2}{*}{ Treatment } & \multicolumn{2}{|c|}{$\operatorname{SRP}(\mu \mathrm{M})$} & \multirow{2}{*}{$\begin{array}{l}\text { TDP }(\mu \mathrm{M}) \\
\text { Final }\end{array}$} & \multicolumn{2}{|c|}{$\mathrm{PO}_{4}$ uptake } & \multirow{2}{*}{$\begin{array}{c}\mathrm{PO}_{4} \text { turnover } \\
\text { time }(\mathrm{h})\end{array}$} & \multirow[t]{2}{*}{$\mathrm{BF}$} \\
\hline & & Initial & Final & & $\mu \mathrm{Ci} \mathrm{l}^{-1} \mathrm{~h}^{-1}$ & $n \mathrm{M} \mathrm{h}^{-1}$ & & \\
\hline \multirow[t]{4}{*}{21 Nov 1991} & None & $0.07 \pm 0.01$ & $0.07 \pm 0.01$ & $1.14 \pm 0.26$ & $2.23 \pm 0.01$ & $2.8 \pm 0.01$ & 20 & - \\
\hline & $\mathrm{PO}_{4}$ & - & $1.16 \pm 0.04$ & $3.28 \pm 0.09$ & $0.20 \pm 0.02$ & - & 233 & 1.00 \\
\hline & Mix A & - & 0.18 & $1.62 \pm 0.02$ & $1.80 \pm 0.05$ & - & 28 & 0.04 \\
\hline & Mix B & - & $0.77 \pm 0.03$ & $1.90 \pm 0.03$ & $0.70 \pm 0.01$ & - & 63 & 0.20 \\
\hline \multirow[t]{4}{*}{7 Jan 1992} & None & $0.10 \pm 0.00$ & $0.02 \pm 0.01$ & - & $1.28 \pm 0.02$ & $2.6 \pm 0.05$ & 40 & - \\
\hline & $\mathrm{PO}_{4}$ & $0.52 \pm 0.07$ & $0.40 \pm 0.05$ & - & $0.31 \pm 0.02$ & $3.4 \pm 0.21$ & $175(324)^{\mathrm{d}}$ & 1.00 \\
\hline & Mix A & $0.10 \pm 0.01$ & $0.15 \pm 0.01$ & - & $1.40 \pm 0.05$ & $3.0 \pm 0.10$ & 35 & -0.02 \\
\hline & Mix B & $0.16 \pm 0.02$ & $0.19 \pm 0.03$ & - & $0.85 \pm 0.11$ & 3.5 & 57 & 0.06 \\
\hline \multirow[t]{12}{*}{13 Feb 1992} & None & $0.17 \pm 0.01$ & - & $0.29 \pm 0.05$ & $0.81 \pm 0.02$ & $2.1 \pm 0.04$ & 40 & - \\
\hline & $\mathrm{PO}_{4}$ & $0.67 \pm 0.05$ & $0.33 \pm 0.00$ & $0.81 \pm 0.01$ & $0.17 \pm 0.04$ & $2.7 \pm 0.70$ & $210(433)$ & 1.00 \\
\hline & Mix A & - & $0.24 \pm 0.04$ & $1.20 \pm 0.02$ & $0.55 \pm 0.04$ & $1.9 \pm 0.13$ & 56 & 0.04 \\
\hline & Mix B & - & $0.75 \pm 0.05$ & $1.34 \pm 0.01$ & $0.42 \pm 0.01$ & $2.7 \pm 0.05$ & 74 & 0.09 \\
\hline & $\mathrm{G}-1-\mathrm{P}$ & - & $0.11 \pm 0.02$ & $1.23 \pm 0$ & $0.56 \pm 0.02$ & $2.6 \pm 0.10$ & 42 & 0.01 \\
\hline & $F-1,6-P$ & - & $0.01 \pm 0.05$ & $1.16 \pm 0.05$ & $0.75 \pm 0.03$ & $2.1 \pm 0.10$ & 42 & 0.01 \\
\hline & PEP & - & $0.17 \pm 0.02$ & 1.26 & $0.68 \pm 0.08$ & $1.8 \pm 0.20$ & 46 & 0.02 \\
\hline & GYP & - & $0.71 \pm 0.19$ & $1.26 \pm 0.00$ & $0.75 \pm 0.02$ & $2.0 \pm 0.04$ & 50 & 0.03 \\
\hline & ATP & - & $0.82 \pm 0.03$ & $1.15 \pm 0.03$ & $0.41 \pm 0.02$ & $1.5 \pm 0.06$ & 71 & 0.08 \\
\hline & GDP & - & $0.79 \pm 0.03$ & $1.22 \pm 0.01$ & $0.40 \pm 0.01$ & $1.9 \pm 0.04$ & 74 & 0.09 \\
\hline & UDP & - & $0.97 \pm 0.04$ & $1.21 \pm 0.08$ & $0.51 \pm 0.03$ & $2.0 \pm 0.11$ & 71 & 0.08 \\
\hline & PPP & - & $0.16 \pm 0.02$ & $1.22 \pm 0.07$ & $0.59 \pm 0.03$ & $2.9 \pm 0.16$ & 50 & 0.03 \\
\hline \multirow[t]{9}{*}{15 Jul 1992} & None & $0.10 \pm 0$ & & $0.27 \pm 0.03$ & $1.63 \pm 0.08$ & $3.4 \pm 0.16$ & 29 & - \\
\hline & $\mathrm{PO}_{4}$ & $0.54 \pm 0.05$ & $0.51 \pm 0.05$ & $0.75 \pm 0.03$ & $0.44 \pm 0.07$ & $4.4 \pm 0.67$ & $132(236)$ & 1.00 \\
\hline & G-1-P & $0.10 \pm 0.01$ & $0.11 \pm 0.01$ & $1.36 \pm 0.12$ & $1.54 \pm 0.08$ & $3.4 \pm 0.18$ & 32 & 0.01 \\
\hline & $F=1,6-P$ & $0.11 \pm 0.01$ & $0.13 \pm 0.01$ & $1.23 \pm 0.02$ & $1.53 \pm 0.03$ & $3.5 \pm 0.06$ & 32 & 0.01 \\
\hline & PEP & $0.10 \pm 0.02$ & $0.29 \pm 0.01$ & $1.40 \pm 0.11$ & $1.38 \pm 0.09$ & $3.7 \pm 0.24$ & 35 & 0.03 \\
\hline & GYP & $0.13 \pm 0.01$ & $0.44 \pm 0.01$ & $1.30 \pm 0$ & $1.31 \pm 0.18$ & $4.3 \pm 0.60$ & 36 & 0.03 \\
\hline & ATP & $0.10 \pm 0.01$ & $0.84 \pm 0.01$ & $1.13 \pm 0.09$ & $1.00 \pm 0.09$ & $4.1 \pm 0.36$ & 52 & 0.11 \\
\hline & GDP & $0.14 \pm 0.01$ & $0.75 \pm 0.03$ & $1.38 \pm 0.11$ & $0.78 \pm 0.05$ & $3.8 \pm 0.25$ & 60 & 0.15 \\
\hline & UDP & $0.09 \pm 0.01$ & $0.82 \pm 0.01$ & $1.24 \pm 0.15$ & $1.12 \pm 0.11$ & $4.5 \pm 0.45$ & 43 & 0.07 \\
\hline \multirow[t]{8}{*}{5 Aug 1992} & None & $0.13 \pm 0.01$ & $0.08 \pm 0.01$ & $0.30 \pm 0.01$ & $0.90 \pm 0.02$ & $1.7 \pm 0.04$ & 61 & - \\
\hline & $\mathrm{PO}_{4}$ & $0.60 \pm 0.02$ & $0.55 \pm 0.01$ & $0.79 \pm 0.01$ & $0.17 \pm 0.03$ & $1.8 \pm 0.27$ & $349(611)$ & 1.00 \\
\hline & $\mathrm{G}-1-\mathrm{P}$ & $0.14 \pm 0.00$ & $0.11 \pm 0.01$ & $1.34 \pm 0.02$ & $0.73 \pm 0.03$ & $1.9 \pm 0.07$ & 74 & 0.02 \\
\hline & $F-1,6-P$ & $0.13 \pm 0.01$ & $0.13 \pm 0.01$ & $1.27 \pm 0.07$ & $0.72 \pm 0.13$ & $1.8 \pm 0.32$ & 75 & 0.03 \\
\hline & GYP & $0.13 \pm 0.01$ & $0.19 \pm 0.02$ & $1.35 \pm 0.10$ & $0.68 \pm 0.03$ & $1.8 \pm 0.09$ & 81 & 0.04 \\
\hline & GDP & $0.14 \pm 0.01$ & $0.45 \pm 0.04$ & $1.37 \pm 0.04$ & $0.51 \pm 0.06$ & $1.9 \pm 0.21$ & 104 & 0.08 \\
\hline & UDP & $0.13 \pm 0.01$ & $0.34 \pm 0.02$ & $1.31 \pm 0.01$ & $0.58 \pm 0.02$ & $1.9 \pm 0.08$ & 93 & 0.06 \\
\hline & PPP & $0.14 \pm 0.01$ & $0.21 \pm 0$ & $1.46 \pm 0.09$ & $0.49 \pm 0.02$ & $1.6 \pm 0.07$ & 110 & 0.09 \\
\hline
\end{tabular}

(Fig. 2). However, in no case was the BF $>0.15$ indicating that even the more utilizable substrates had a relatively low preference index compared to $\mathrm{PO}_{4}$ added at equimolar concentrations.

In the experiments where compound mixtures were tested, the monophosphate esters (Mix A) always displayed lower bioavailability factors than Mix B containing the nucleotides plus the inorganic polyphosphate (Table 1). On one occasion, 7 January 1992, Mix A appeared to have a slight stimulatory effect $(B F=-0.02)$ and the rate of uptake in this treatment was slightly higher than that of the control (Table 1). A similar phenomenon was sometimes observed for selected compounds in previous studies (Berman 1988, Bentzen \& Taylor 1991).

\section{Phosphate regeneration}

Increases in SRP concentrations and attendant decreases in ${ }^{32} \mathrm{P}$ uptake rates were observed in several combined-phosphorus-supplemented incubations 
Fig. 1 Representative experimental re sults for ${ }^{32} \mathrm{PO}_{4}$ uptake into particulate matter and documentation of radiochemical mass balances during bottle incubations. (A) No addition, (B) $0.5 \mu \mathrm{M}$ $\mathrm{PO}_{4}$ added, (C) $1 \mu \mathrm{MP}$ added as Mix A. (equimolar $P$ additions of $F-1,6-P, G-1-P$, GYP and PEP), (D) $1 \mu \mathrm{M} P$ added as Mix $B$ (equimolar $P$ additions of ATP, GDP, UDP and PPP). See text for combined P abbreviations. (D) Total ${ }^{32} \mathrm{P}$ activity in whole water sample, $(0.45 \mu \mathrm{m}$ particulate ${ }^{32} \mathrm{P}$ activity $(\mathbf{\Delta}) 0.45 \mu \mathrm{m}$ filtrate. Error bars (which are generally less than the size of the respective symbols) indicate \pm 1 standard deviation of the mean $(\mathrm{n}=3)$

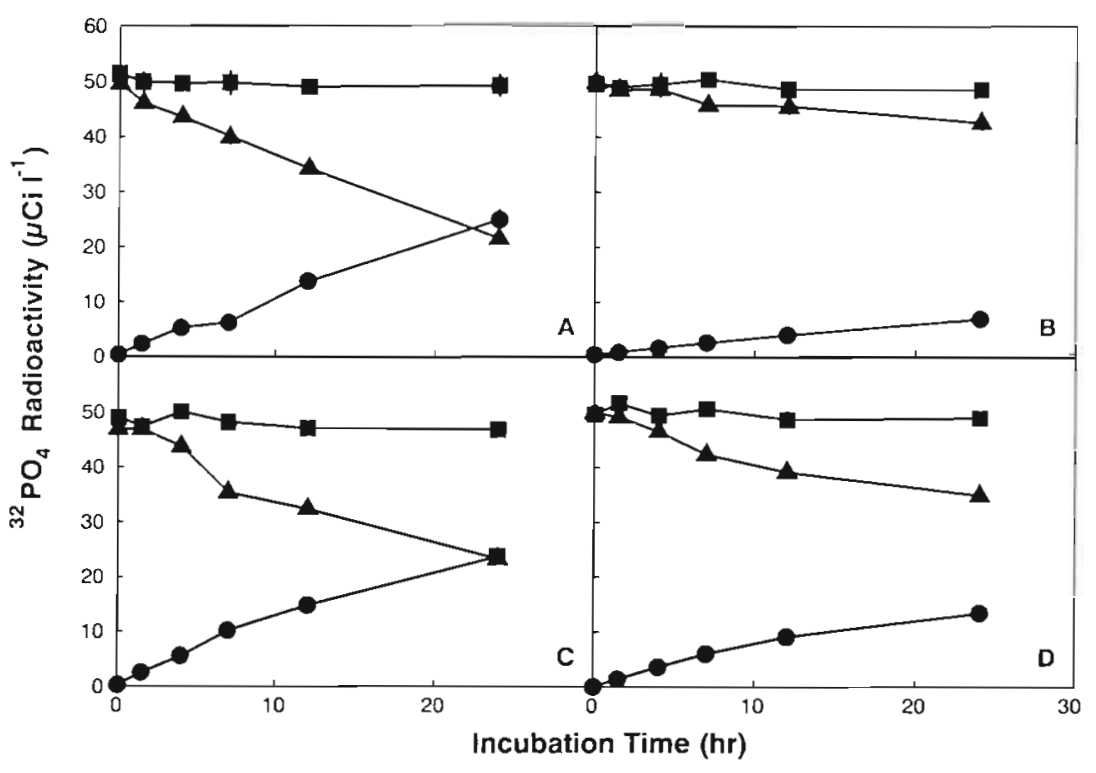

Size fractionation experiments

(Table 2, Fig. 3). These results suggest that much of the phosphate released from these selected compounds mixed with the ambient SRP pool, and that the sparing effect observed in these experiments was probably the result of isotope dilution by the regenerated phosphorus. These results also suggest that the hydrolysis of DOP was not tightly coupled to uptake in these microbial assemblages, even though a fraction of the unlabelled phosphate released was indeed incorporated into the particulate fraction.

Phosphate regeneration from a DOP compound in a mixture was similar to the behavior of the compound when added individually. This suggests that the compound was preferred the same in the single substrate incubation as in the respective mixture (Table 2).

The accumulation of SRP was especially prominent in treatments supplemented with nucleotides. In most experiments 65 to $95 \%$ of the DOP from the selected nucleotides was converted to SRP after a $24 \mathrm{~h}$ incubation period. By comparison, generally less than $25 \%$ of added phosphorus from the substrates G-1-P, F-1,6-P and PEP accumulated as SRP. The results for GYP and PPP varied among experiments (Table 2). On 5 August lower net accumulations of SRP were observed for all compounds compared to earlier experiments (Table 2). The overall uptake rates were also slower, and turnover times longer (Table 1), implying that total community activity was lower. which may explain the less pronounced SRP accumulation observed.

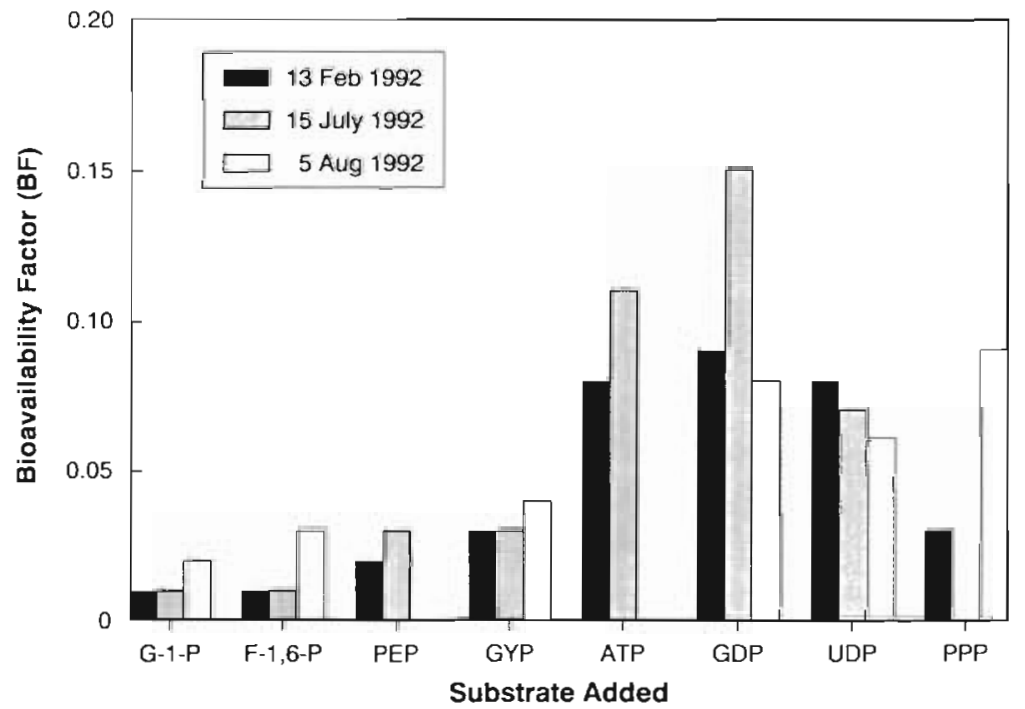

Fig. 2. Bioavailability factors (BF) for a variety of phosphorus compounds (added at $1 \mu \mathrm{M}$ concentrations) on 3 separate sampling dates. BF was calculated by measuring the sparing effect of each compound on the uptake of ${ }^{32} \mathrm{PO}_{4}$, relative to control samples with and without added $\mathrm{PO}_{4}$. A BF value of 1 indicates that the test compound has a bioavailability equivalent to $\mathrm{PO}_{4}$, and a $\mathrm{BF}$ value of 0 indicates that the compound is not available to the cells. See text for additional details and for combined $\mathrm{P}$ abbreviations 
Table 2. SRP regeneration from selected combined P compounds and compound mixtures expressed as net accumulations of SRP following a $24 \mathrm{~h}$ incubation period. All compounds were added as $1 \mu \mathrm{M}$ total P. Values are means $\pm 1 \mathrm{SD}$; if no $\mathrm{SD}$ is given then $\mathrm{n}=1$

\begin{tabular}{|c|c|c|c|c|}
\hline \multirow{2}{*}{ Treatment } & \multicolumn{4}{|c|}{ Net SRP accumulation $(\mu \mathrm{M})^{\mathrm{d}}$} \\
\hline & 13 Feb 1992 & 5 May 1992 & 15 Jul 1992 & 5 Aug 1992 \\
\hline G-1-P & $0.11 \pm 0.02$ & $0.06 \pm 0.01$ & $0.11 \pm 0.01$ & $0.03 \pm 0.01$ \\
\hline$F-1,6-P$ & $0.01 \pm 0.05$ & $<0.01$ & $0.13 \pm 0.01$ & $0.05 \pm 0.01$ \\
\hline PEP & $0.17 \pm 0.02$ & $0.21 \pm 0.03$ & $0.29 \pm 0.01$ & - \\
\hline GYP & $0.71 \pm 0.19$ & $0.58 \pm 0.08$ & $0.44 \pm 0.01$ & $0.11 \pm 0.02$ \\
\hline \multicolumn{5}{|l|}{$\operatorname{Mix} A^{b}$} \\
\hline Predicted & 0.25 & 0.21 & - & - \\
\hline Observed & $0.24 \pm 0.04$ & $0.21 \pm 0.04$ & & \\
\hline ATP & $0.82 \pm 0.03$ & $0.64 \pm 0.07$ & $0.84 \pm 0.01$ & - \\
\hline GDP & $0.79 \pm 0.03$ & $0.65 \pm 0.02$ & $0.75 \pm 0.03$ & $0.37 \pm 0.04$ \\
\hline UDP & $0.97 \pm 0.04$ & $0.73 \pm 0.02$ & $0.82 \pm 0.01$ & $0.26 \pm 0.02$ \\
\hline \multirow{2}{*}{\multicolumn{5}{|c|}{$\mathrm{Mix} \mathrm{B}^{\mathrm{c}}$}} \\
\hline & & & & \\
\hline Predicted & $0.69 \pm 0.03$ & $0.67 \pm 0.06$ & - & - \\
\hline Observed & $0.75 \pm 0.05$ & $0.52 \pm 0.04$ & & \\
\hline \multicolumn{5}{|c|}{ 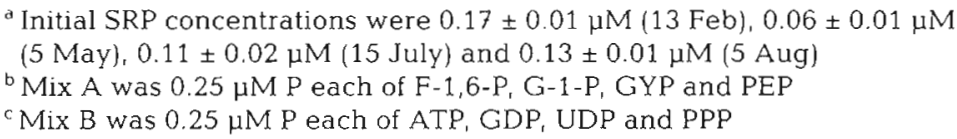 } \\
\hline
\end{tabular}

ular, the ability to exploit phosphorus from the DOP pool may be crucial to the recycling and bioavailability of phosphate especially because the concentration ratio of DOP to SRP often is $>1$, and can exceed 10 , in selected environments (Orrett \& Karl 1987, Karl \& Tien 1992, Fourqurean et al. 1993). The bioavailability and the composition of this potential source of phosphorus to the microbial community are largely unknown.

Even though the chemical composition of the naturally occurring DOP is poorly known, it seems evident that aquatic bacteria and phytoplankton do have enzyme systems appropriate for DOP hydrolysis (Chróst \& Overbeck 1987, Tarapchak \& Moll 1990). Consequently, they are able to utilize existing organic phosphorus sources, though to varying degrees (Chu 1946, Kuentzler 1965, 1970, Currie 1986, Bentzen \& Taylor 1991, Berman et al. 1991, Cooper et al. 1991, van Boekel 1991). In this study, distinct differences in the

there was not a unique separation between bacteria and phytoplankton, the $\geq 0.8 \mu \mathrm{m}$ and $<0.8 \mu \mathrm{m}$ fractions were enriched in algae and bacteria, respectively.

Over shorter incubation periods, the same general size fractionation pattern was observed, with the bacterial-enriched fraction dominating the uptake and the $>0.8 \mu \mathrm{m}$ fraction never exceeding $50 \%$ of total particulate activity at any time, with one exception in the positive control when $87 \%$ of overall particulate activity was found in this fraction after a $7 \mathrm{~h}$ incubation period. The total particulate ${ }^{32} \mathrm{P}$ activity in this sample was, however, only approximately $5 \%$ of the total ${ }^{32} \mathrm{P}$ inventory, as compared to 13-20\% for the other treatments. Consequently, small changes in uptake into the different size fractions result in large relative changes.

\section{DISCUSSION}

Marine ecosystems have not, in general, been regarded as phosphorus limited for primary and secondary microbial production, but large oceanic areas typically have phosphorus concentrations that are undetectable by standard procedures ( $\leq 50 \mathrm{nM}$ ) much of the time. Consequently, the availability of phosphorus may ultimately control biomass and organic production in certain marine environments (Smith et al. 1986, Codispoti 1989). In oligotrophic oceanic habitats, such as the central North Pacific Ocean (Karl et al. 1993), the regeneration of phosphate within the euphotic zone could be an important regulating factor. In particbioavailability of various phosphorus compounds tested were observed; still there was no strong coupling between hydrolysis and subsequent uptake of the regenerated phosphate. Also, in comparison to findings of Bentzen \& Taylor (1991), who showed sparing effects in the uptake of ${ }^{32} \mathrm{PO}_{4}$ from G-1-P treatments of approximately $50 \%$ relative to unsupplemented controls, we never observed an effect that exceeded a few percent. Even our most preferred

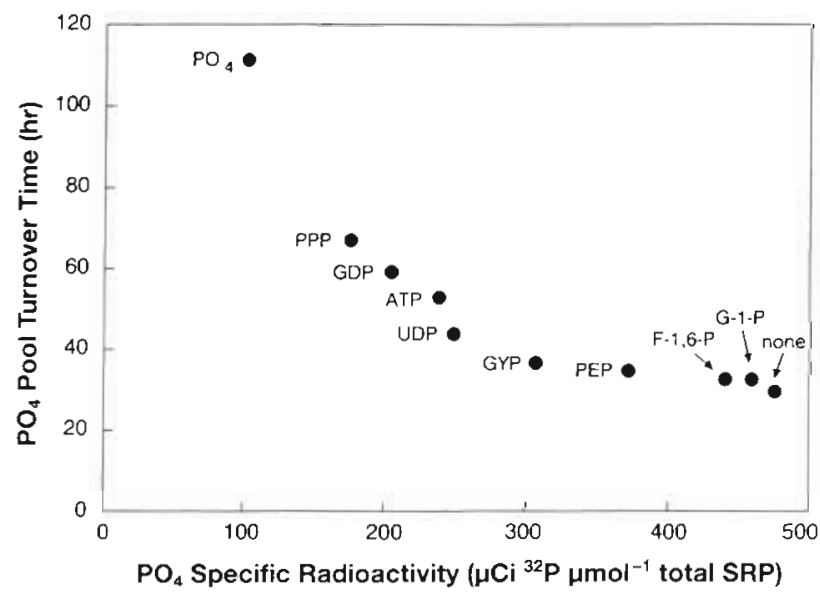

Fig. 3. Relationships between $\mathrm{PO}_{4}$ pool turnover time and $\mathrm{PO}_{4}$ pool specific radioactivity following a $12 \mathrm{~h}$ incubation period in the presence of exogenous $\mathrm{P}$ compounds. The decrease in specific radioactivity and increase in turnover time relative to the negative control (no added P) are both indicative of $S R P$ regeneration during the incubation period. See text for combined P abbreviations 


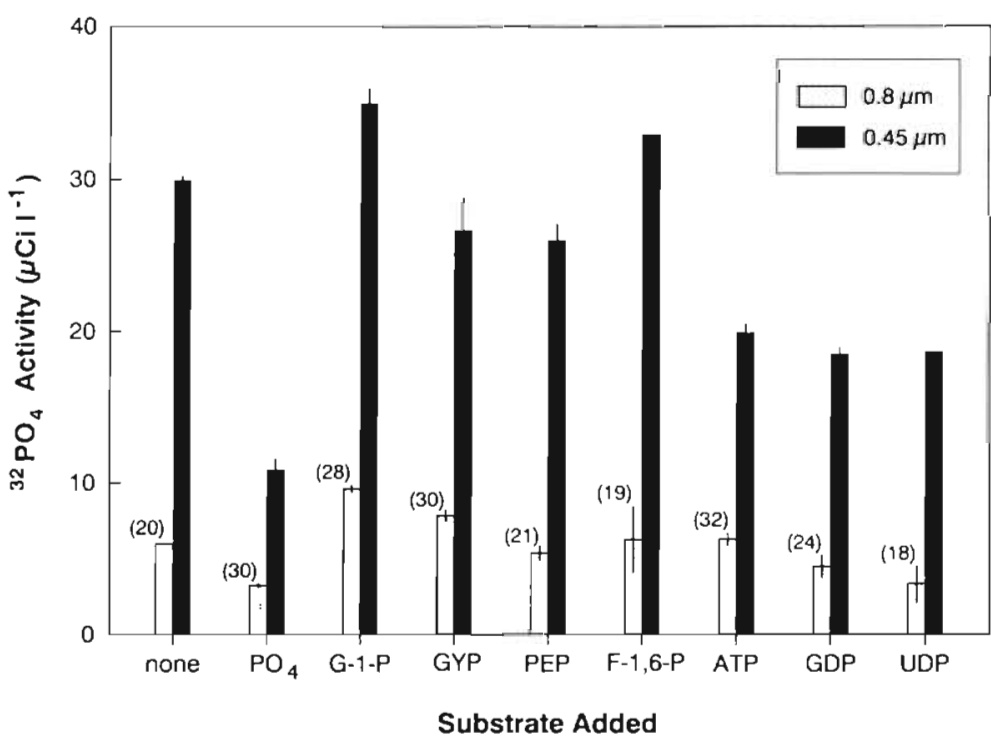

Fig. 4. Distribution of particulate activity in 2 different size fractions $(\geq 0.8 \mu \mathrm{m}$ and $\geq 0.45$ to $0.8 \mu \mathrm{m}$ ) following a $24 \mathrm{~h}$ incubation period. The value given in parentheses above each $\geq 0.8 \mu \mathrm{m}$ data point is the mean percentage of the total activity that is in the $\geq 0.8 \mu \mathrm{m}$ fraction

metabolic rates. The latter would be expected if the microbial assemblages were nutrient or energy limited by a constituent other than phosphorus

There are reports demonstrating that a significant flux of phosphorus may pass via DOP through the microbial food web in selected aquatic ecosystems (Orrett \& Karl 1987, Berman 1988). It has also been suggested that the smallest components of the planktonic community, predominantly the heterotrophic bacteria, could act as a sink for orthophosphate in oligotrophic lakes. Bacteria could outcompete algae for phosphate, at least at low ambient concentrations and during short incubation periods, leaving the phytoplankton to rely on less readily available sources of phosphorus (e.g. phosphorus compounds) to meet their metabolic requirements (Currie \& Kalff 1984a, Currie 1986, Currie et al. 1986, Berman 1988, Tamminen 1989, Jürgens \& Güde 1990, Bentzen \& Taylor 1991, Berman et al. 1991). There are, how-

phosphorus compound, GDP, never exceeded 0.15 on our relative preference index scale and orthophosphate $\left(\mathrm{PO}_{4}\right)$ was always the preferred substrate. These differences may reflect variations in the capability to exploit a variety of phosphorus compounds within the habitats investigated, resulting in preferential utilization of the different compounds tested.

In the marine environment where this study was conducted the uptake rates were lower and turnover times much longer than those generally reported from oligotrophic freshwater systems, which can have turnover times on the order of minutes (Rigler 1964, Lean \& Nalewajko 1979). The approximately 3 -fold variation in $\mathrm{PO}_{4}$ uptake rates among sampling dates (range of 1.5 to $4.5 \mathrm{nM} \mathrm{h}^{-1}$ ) could reflect changes in population structure on these dates or variations in overall community activity. Such temporal variation might be expected for coastal oceanic habitats. Note, however, that for any given sampling date the uptake rates of phosphate, after correcting for the isotope dilution, were similar regardless of the phosphorus compound added. This suggests that the overall uptake rate of phosphate was more or less constant and that no apparent stimulation or repression occurred as a result of the phosphorus additions made (Table 1 ). The relatively low uptake rates we observed in Hawaiian coastal waters are within the range of rates previously estimated from similar marine environments (Harrison et al. 1977, Smith et al. 1985, Harrison \& Harris 1986). These low rates may not, however, simply be a reflection of low biomass but may also reflect low per capita ever, several studies that have demonstrated just the opposite. For example, Cotner \& Wetzel (1992) showed that algae always retained phosphorus over longer incubation periods than bacteria, even if bacteria initially were more efficient in sequestering phosphate from the medium. Tarapchak \& Moll (1990) also indicated that phytoplankton, in general, are responsible for the majority of phosphate uptake. In our experiments from a coastal subtropical marine environment, the $<0.8 \mu \mathrm{m}$ (bacterial-enriched) fraction always dominated the overall phosphate uptake even after $24 \mathrm{~h}$ incubation periods. These results indicate that the bacterial-enriched fraction of the microbial community, which also contained small algal cells, was able to effect a more rapid uptake than the algal-enriched fraction $(\geq 0.8 \mu \mathrm{m})$, and was more efficient at retaining the acquired phosphorus for extended periods of time.

Phosphorus compounds are not known to be assimilated intact but rather are hydrolyzed prior to uptake (Reid \& Wilson 1971, Chróst 1990). Phosphatase activity, with alkaline phosphatase (APase) as the most ubiquitous enzyme, can be responsible for the majority of hydrolysis of phosphorus compounds occurring in oligotrophic aquatic environments (Kobori \& Taga 1978, Karl \& Craven 1980), and APase activity could meet the requirements of the phytoplankton. Ammerman \& Azam (1985) have also documented 5'-nucleotidase in seawater, and Tamminen (1989) estimated that the activity of this bacterial ectoenzyme could fulfill bacterial phosphorus needs. As observed in our study, substantial amounts of SRP accumulated during 
incubations with selected combined phosphorus additions. Similar results were reported by Tamminen (1989), who estimated that as much as $80 \%$ of the phosphate hydrolyzed from DOP could be released into the environment due to the activity of the enzyme 5 -nucleotidase. It thus appears that this hydrolytic enzyme may function primarily as a mechanism to sequester the carbon-nitrogen residue in order to acquire biosynthetic precursors or to meet other metabolic requirements rather than as a phosphorus assimilation system.

Even though we did not measure enzyme activities directly, the extensive accumulation of SRP observed during incubations supplemented with nucleotides could reasonably be attributed to enzymatic activities similar or identical to those ascribed to 5 '-nucleotidase. However, nucleotides are also substrates for APase, so this evidence by itself is not diagnostic. In contrast to 5 -nucleotidase, APase is susceptible to end-product inhibition by phosphate (Bengis-Garber \& Kushner 1981, 1982, Ammerman \& Azam 1985) and, therefore, APase activity may be influenced by ambient $\mathrm{PO}_{4}$ concentrations. Furthermore, the monophosphate esters, which are known to be hydrolyzed by APase, did not produce large SRP accumulations relative to the treatments supplemented with nucleotides. Substrates to 5 '-nucleotidase were, however, readily hydrolyzed, indicating that this enzyme may have a major role in DOP regeneration in the habitats investigated.

The SRP accumulation observed, suggesting enzymatic activities such as those of 5 -nucleotidase, also suggests that the microbial assemblages in the habitats we investigated may have preferentially utilized the carbon-nitrogen complex rather than the phosphorus portion of the nucleotides. Other studies have concluded that bacteria under certain circumstances are primarily carbon limited (Azam et al. 1983, Jürgens \& Güde 1990), and this may also be true for the habitats we investigated. Preliminary results from enrichment experiments with both additional carbon and nitrogen indicated that organic carbon (added as sucrose) had substantial stimulatory effects on the uptake rates of phosphate, increasing the rate by approximately a factor of 2 relative to controls. The simultaneous addition of nitrogen $\left(\mathrm{NO}_{3}\right)$ did not appear to affect the uptake rate in these experiments (data not shown). However, it is important to emphasize that we did not trace either $\mathrm{C}$ or $\mathrm{N}$ in any of our test compounds so further comments regarding rates and processes would be speculative

The results of our study indicate that the different phosphorus compounds tested are potential sources of phosphorus for these marine communities and that the phosphorus compounds differed with respect to their bioavailabilities. Also, the utilization of these compounds as a source for phosphorus may be indirect, rather than a direct and coupled uptake of phosphate after hydrolysis. The high rates of SRP accumulation during the incubations implies that the hydrolytic processes could potentially release considerable amounts of the nutrient into the surrounding water, thus making it available to other organisms in the ecosystem. The action of 5'-nucleotidase, for example, could thus provide the heterotrophic microbial community with exogenous carbon and nitrogen, as well as phosphorus.

Because our knowledge to date is limited with respect to DOP pool composition it should be emphasized that incubation experiments with substantial additions of DOP may not accurately reflect the rates and pathways in nature. They do, however, provide indications as to the metabolic potential of the systems investigated as well as elucidating certain limitations of the ambient microbial community at various times.

In conclusion, the substantial differences in the bioavailability of various phosphorus compounds we measured illustrates the need for further studies on the composition of naturally occurring DOP and other phosphorus sources in order to resolve the biogeochemical cycle of phosphorus.

Acknowledgements. The authors thank 3 anonymous referees for constructive criticisms on an earlier version of this manuscript and Lisa Lum for her assistance in the preparation of text and figures. This research was supported, in part, by National Science Foundation grants OCE88-00329 (awarded to D. Karl and C. Winn), OCE93-01368 (awarded to D. Karl, D. Hebel and L. Tupas) and by 3 travel grants awarded to the senior author (Helge Ax:son Johnson's Foundation, O. E and Edla Johanssons Science Foundation, Wallenberg's Jubilee Fund). SOEST Contribution \#3579.

\section{LITERATURE CITED}

Ammerman, J. W. (1991). Bacterial 5'-nucleotidase activity in estuarine and coastal marine waters: role of phosphorus regeneration. Limnol. Oceanogr. 36: 1437-1447

Ammerman, J W., Azam, F. (1985). Bacterial 5'-nucleotidase in aquatic ecosystems; a novel mechanism of phosphorus regeneration. Science 207:1338-1340

Ammerman, J. W., Azam, F. (1991). Bacterial 5'-nucleotidase activity in estuarine and coastal waters. Characterization of enzyme activity. Limnol. Oceanogr. 36: 1427-1436

Azarn, F., Fenchel, T., Field, J. G., Gray, J. S., Meyer-Reıl, L.-A., Thingstad, F. (1983). The ecological role of water column microbes in the sea. Mar. Ecol. Prog. Ser. 10: $257-263$

Bengis-Garber, C., Kushner, D. J. (1981). Purification and properties of 5'-nucleotidase from the membrane of Vibrio costicola, a moderate halophilic bacterium. J. Bacteriol. 146: $24-32$

Bengis-Garber, C., Kushner, D. J. (1982). Role of membrane bound 5 -nucleotidase in nucleotide uptake by a moderate halophile Vibrio costicola. J. Bacteriol. 149: 808-815 
Bentzen, E., Taylor, W. D. (1991). Estimating organic P utilization by fresh water plankton using $\left[{ }^{32} \mathrm{P}\right]$ ATP. J. Plankton Res. 13: 1223-1238

Bentzen, E., Taylor, W. D., Millard, E. S. (1992). The importance of organic phosphorus to phosphorus uptake by limnetic plankton. Limnol. Oceanogr. 37: 217-231

Berman, T (1988). Differential uptake of orthophosphate and organic phosphorus substrates by bacteria and algae in Lake Kinneret. J. Plankton Res. 10: 1239-1249

Berman, T., Chava, S., Kaplan, B., Wynne, D. (1991). Dissolved organic substrates as phosphorus and nitrogen sources for axenic batch cultures of fresh water green algae. Phycologia 30: 339-345

Chróst, R. J. (1990). Microbial ectoenzymes in aquatic environments, In: Overbeck, J., Chróst, R. J. (eds.) Aquatic microbial ecology: biochemical and molecular approaches Springer-Verlag, New York, p. 47-78

Chróst, R. J., Overbeck, J. (1987). Kinetics of alkaline phosphatase activity and phosphorus availability for phytoplankton and bacterioplankton in Lake PluBsee (North German eutrophic lake). Microb. Ecol. 13: 229-248

Chu, S. P. (1946). Utilization of arganic phosphorus by phytoplankton. J. mar. biol. Ass. U.K. 26: 285-295

Codispoti, L. A. (1989). Phosphorus vs. nitrogen limitations in new and export production. In: Berger, W. H., Smetacek, V.S., Wefer, G. (eds.) Productivity of the oceans: present and past. John Wiley \& Sons Ltd, Chichester, p. 377-394

Cooper, J. E., Early, J., Holding, A. J. (1991). Mineralization of dissolved organic phosphorus from a shallow eutrophic lake. Hydrobiologia 209: 89-94

Cotner, J. B., Wetzel, R. G. (1992). Uptake of dissolved inorganic and organic phosphorus compounds by phytoplankton and bacterioplankton. Limnol. Oceanogr. 37: 232-243

Cotner, J. B., Wetzel, J. R., Wetzel, R. G. (1991). 5 '-Nucleotidase activity in a eutrophic lake and an oligotrophic lake. Appl environ. Microbiol. 57: 1306-1312

Currie, D. J. (1986). Does orthophosphate uptake supply sufficient phosphorus to phytoplankton to sustain their growth? Can. J. Fish. Aquat. Sci. 43: 1482-1487

Currie, D. J., Bentzen, E., Kalff, J. (1986). Does algal-bacterial phosphorus partitioning vary among lakes? A comparative study of orthophosphate uptake and alkaline phosphatase activity in fresh water. Can. J. Fish. Aquat. Sci. 43: 311-318

Currie, D. J., Kalff, J. (1984a). A comparison of the ability of freshwater algae and bacteria to aquire and retain phosphorus. Limnol. Oceanogr. 29: 298-310

Currie, D. J., Kalff, J. (1984b). The relative importance of bacterioplankton and phytoplankton in phosphorus uptake in freshwater. Limnol. Oceanogr. 29: 311-321

Fourqurean, J. W., Jones, R. D., Zieman, J. C. (1993). Processes influencing water column nutrient characteristics and phosphorus limitation of phytoplankton biomass in Florida Bay, FL, USA: inferences from spatial distribution. Estuar. coast. Shelf Sci. 36: 295-314

Goldman, J. C., McCarthy, J. J., Peavy, D. G. (1979). Growth rate influence on the chemical composition of phytoplankton in oceanic waters. Nature 279: 210-215

Harrison, W. G., Azam, F., Renger, E. H., Eppley, R. W. (1977). Some experiments on phosphate assimilation by coastal marine plankton. Mar. Biol. 40: 9-18

Harrison, W. G., Harris, L. R. (1986). Isotope-dilution and its effects on measurements of nitrogen and phosphorus uptake by oceanic microplankton. Mar. Ecol. Prog. Ser. 27: $253-261$

Jeffries, D. S., Dieken, F. P., Jones, D. E. (1979). Performance of the autoclave digestion method for total phosphorus analysis. Water Res. 13: 275-279

Jürgens, K., Güde, H. (1990). Incorporation and release of phosphorus by planktonic bacteria and phagotrophic flagellates. Mar. Ecol. Prog. Ser. 59: 271-284

Karl, D. M., Craven, D. B. (1980). Effects of alkaline phosphatase activity on nucleotide measurements in aquatic microbial communities. Appl. environ. Microbiol. 40 549-561

Karl, D. M., Tien, G. (1992). MAGIC: a sensitive and precise method for measuring dissolved phosphorus in aquatic environments. Limnol. Oceanogr. 37. 105-116

Karl, D. M., Tien, G., Dore, J., Winn, C. D. (1993). Total dissolved nitrogen and phosphorus concentrations at USJGOFS station ALOHA: Redfield reconciliation. Mar. Chem. 41: 203-208

Kobori, H., Taga, N. (1978). Phosphatase activity and its role in mineralization of organic phosphorus in coastal water. J. exp. mar. Biol. Ecol. 36: 23-39

Kuentzler, E. J. (1965). Glucose-6-phosphate utilization by marine algae. J. Phycol. 1: 156-164

Kuentzler, E. J. (1970). Dissolved organic phosphorus excretion by marine phytoplankton. J. Phycol. 6: 7-13

Lean, D. R. S., Nalewajko, C. (1979). Phosphorus turnover times and phosphorus demand in large and small lakes. Arch. Hydrobiol. 13: 120-132

Murphy, J., Riley, J. P. (1962). A modified single solution method for determination of phosphate in natural waters Anal. Chim. Acta 27: 31-36

Orrett, K., Karl, D. M. (1987). Dissolved organic phosphorus production in surface seawater. Limnol. Oceanogr. 32 383-395

Perry, M. J. (1972). Alkaline phosphatase activity in subtropical Central North Pacific waters using a sensitive fluorometric method. Mar. Biol. 15: 113-119

Perry, M. J., Eppley, R. W. (1981). Phosphate uptake by phytoplankton in the central North Pacific Ocean. Deep Sea Res. 28A: $39-49$

Reid, T W., Wilson, I. B. (1971). E. coli alkaline phosphatase In: Boyer, P. D. (ed.) The enzymes, Vol. IV, Hydrolysis, 3rd edn. Academic Press, New York, p. 373-415

Rigler, F. H. (1964). The phosphorus fraction and the turnover time of inorganic phosphorus in different types of lakes. Limnol. Oceanogr. 9: 511-518

Ryther, J. H., Dunstan, W. M. (1971). Nitrogen, phosphorus and eutrophication in the marine coastal environment Science 171. 1008-1013

Smith, R. E. H., Harrison, W. G., Harris, L. (1985). Phosphorus exchange in marine microplankton communities near Hawaii. Mar. Biol. 86: 75-84

Smith, S. V., Kimmerer, W. J., Walsh, T W. (1986). Vertical flux and biogeochemical turnover regulate nutrient limitations of net organic production in the North Pacific Gyre. Limnol. Oceanogr. 31. 161-167

Strickland, J. D. H., Parsons, T. R. (1972). A practical book on seawater analysis, 2nd edn. Bull. Fish. Res. Bd Can. 167

Tamminen, $T$ (1989). Dissolved organic phosphorus regeneration by bacterioplankton: 5'-nucleotidase activity and subsequent phosphate uptake in a mesocosm enrichment experiment. Mar. Ecol. Prog. Ser. 58: 89-100

Tarapchak, S. J., Moll, R. A. (1990). Phosphorus sources for phytoplankton and bacteria in Lake Michigan. J. Plankton Res. 12: 743-758

van Boekel, W. H. M. (1991). Ability of Phaeocystis sp. to grow on organic phosphates; direct measurements and prediction with the use of an inhibition constant. J. Plankton Res. 13: $959-970$ 